\title{
Antimutagenicity of Water and Methanol Extracts of Soymilks Fermented by Bifidobacteria and Lactic Acid Bacteria
}

\author{
Isao Kiyosawa ${ }^{*}$, Jun Matsuyama ${ }^{*}$ and Chiaki AraI ${ }^{* *}$ \\ * Department of Agricultural Chemistry, Faculty of Agriculture, \\ Tamagawa University, 6-1-1, Tamagawagakuen, \\ Machida, Tokyo 194 \\ ${ }^{* *}$ Așama Kasei Co. LTD, 20-3, Nihonbashi Kodenma-cho, \\ Chuo-ku, Tokyo 103
}

\begin{abstract}
An antimutagenic effect of the aqueous and $80 \%$ methanol extracts of soymilk was observed on $\mathrm{N}$-methyl-N' $\mathrm{N}^{\prime}$-nitrosoguanidine (MNNG) mutagenesis toward Escherichia coli $\mathrm{B} / \mathrm{r}$ WP $2 \operatorname{trp}^{-}$. Addition of both extracts to the plate decreased the mutation frequency through the dose amount of $60 \mu l$. However, there was a tendency for the mutation frequency to increase with the addition of more than $80 \mu \mathrm{l}$. The effect of the extract prepared from soybeans soaked in water was increased by heating them at $100^{\circ} \mathrm{C}$ for more than $40 \mathrm{~min}$. The $80 \%$ methanol extracts of soymilk fermented by Bifdobacteria adolescentis, $B$. breve, $B$. longum and Streptococcus lactis increased the antimutagenic effect compared with that of unfermented soymilk. The extract of fermented soymilk with $B$. infantis enhanced the MNNG mutagenesis toward $E$. coli. The antimutagenic effects of the fermented milk with $B$. bifidum, S. thermophilus and Lactobacillus acidophilus were lower than that of unfermented soymilk.
\end{abstract}

Extracts of vegetables and fruits exhibit an antimutagenic effect against chemical mutagens such as 3-amino-1, 4-dimethyl-5 H-pyrido [4,3-b] indole (Trp-p-1), 3-amino-1-methyl$5 \mathrm{H}$-pyrido [4,3-b] indole (Trp-p-2) and $\mathrm{N}$ methyl- $\mathrm{N}^{\prime}$-nitro-N-nitrosoguanidine (MNNG) on the mutants of Escherichia coli and Salmonella typhimurium ${ }^{1)-6)}$. Suppressive effects were also observed to occur in the process of food preparation. OBANA et al. ${ }^{7)}$ reported that freshly brewed coffee extracts suppressed the UV-light or chemical mutagenesis in S. typhymurium TA $1535 /$ psk 1002, but green coffeebean extracts did not. In addition, Hosono et $a l^{8)}$ reported that the antimutagenic activities of cow's skim milk against 2-(2-furyl)3-(5-nitro-2-furyl) acrylamide (AF-2) in the streptomycin dependent strains of Salmonella typhimurium TA 98 increased by fermentation with Lactobacillus delbrueckii subsp. bulgaricus and Streptococcus salivarius subsp. thermophilus. The acetone and ethyl acetate extracts from cow's milk fermented by Streptococcus thermophilus and/or Lactobacillus bulgaricus suppressed the mutagenesis of 4-nitroquinoline-N-oxide (4 NQO) and 2-aminofluorene (2$\mathrm{AF}$ ) in S. typhimurium TA 98 and TA $100^{9 \text { ) }}$.

The preparation of yogurt-like products from soymilk has been studied for the improvement of acid production and sensory quality by several workers ${ }^{10) \sim 14}$. However, antimutagenic activity of the fermented soymilk has not been reported so far and the clarification of this activity is of significance for the selection of bacterial strains as starter in the fermentation of soymilk.

In this study, the fermented soymilks were prepared by culturing with several strains of lactic acid bacteria and bifidobacteria, and the effects of each extracts on the chemically in- 
duced mutagenesis toward Escherichia coli $\mathrm{B} / \mathrm{r}$ WP $2 \operatorname{trp}^{-}$were examined.

\section{Materials and Methods}

\section{Reagents and materials}

The soybeans used were Miyagishirome produced at Wakutani-cho, Toda-gun, Miyagi prefecture. A chemical mutagen, MNNG, and dimethylsulfoxide (DMSO) were obtained from Aldrich Chem. Co. and Dojin Chemical Lab., respectively.

Bacterial strains and culture conditions

The following strains of bacteria for fermentation were obtained from the Institute of Physical and Chemical Research (Wako-shi, Saitama) ; Bifidobacterium adolescentis 1275, $B$. bifidum 1255, $B$. breve 1192, $B$. infantis 1222 , B. longum 1217, Streptococcus lactis 208, S. thermophilus 419, Lactobacillus acidophilus 8102, L. bulgaricus 126.

The stock cultures and pre-cultures of these bacteria were prepared using GAM-semi liquid agar medium containing $0.2 \%$ agar (GAM Broth Nissui, Nissui Pharm. Co.) for bifidobacteria and $10 \%$ skimmilk medium for lactic acid bacteria. For the cultivation of $L$. acidophilus, $10 \%$ skim milk $+1 \%$ glucose $+1 \%$ yeast extract (Difco Lab.) was used.

The strain of Escherichia coli B/r WP $2 \operatorname{trp}^{-}$ (IFO 14195) was obtained from the Institute for Fermentation (Yodogawa-ku, Osaka). The bacterial suspension of $E$. coli was prepared by growing overnight in $0.8 \%$ nutrient broth (Difco Lab.) and then $0.7 \mathrm{ml}$ of DMSO was added to $8.0 \mathrm{ml}$ of the culture. The culture was dispensed in $0.2 \mathrm{ml}$ aliquots into screwcap vials and kept at $-80^{\circ} \mathrm{C}$.

\section{Assay of antimutagenic activity}

The semi-enriched minimal agar medium (SEM) was prepared according to the method of KADA and KANEMATSU ${ }^{15)}$. Top agar containing $0.6 \% \mathrm{NaCl}$ and $0.6 \%$ Difco bacto agar was also prepared and kept at $43^{\circ} \mathrm{C}$ before use. The stock strain of $E$. coli was grown in $0.8 \%$ nutrient broth (Difco Lab.) and the pre-culture was incubated at $37^{\circ} \mathrm{C}$ for $16 \mathrm{~h}$ in $\mathrm{B}-2$ broth medium. The cells obtained by centrifugation were washed twice with $1 / 15 \mathrm{M}$ phosphate buffer at $\mathrm{pH} 7.0\left(1-2 \times 10^{9}\right.$ cells $\left./ \mathrm{m} l\right)$. Twenty five $\mathrm{m} l$ of the cell suspension was added to the same volume of MNNG solution $(120 \mu \mathrm{g} / \mathrm{ml}$ of the buffer). The cell-mutagen mixture was incubated at $37^{\circ} \mathrm{C}$ for $30 \mathrm{~min}$ with slow shaking. The treated cells obtained by centrifugation were washed three times with the buffer and resuspended in $25 \mathrm{~m} l$ of the buffer. A mixture of $0.1 \mathrm{ml}$ of the suspension containing mutagenized bacteria and a certain volume of the extract was added to $3 \mathrm{~m} l$ of the top agar and poured onto the SEM plate. The suspension of mutagenized cells was also diluted with the buffer by a factor of $10^{6}$, and a $0.1 \mathrm{ml}$ portion was poured in the same way as described above. Revertants and viable cells were counted after incubation at $37^{\circ} \mathrm{C}$ for 3 days.

Preparation of fermented soymilk

Soybeans were soaked overnight with 3 times their weight of deionized water at room temperature and dehulled. The soaked soybeans were blended for $10 \mathrm{~min}$ in a mixer (Hitachi Co., VA-W 35) by adding 6 parts of boiling water to one part of dry soybeans. The slurry was filtered through 4 thicknesses of gauze. The filtrate was heated at $85^{\circ} \mathrm{C}$ for $20 \mathrm{~min}$ and used as soymilk. One hundred $\mathrm{m} l$ of the soymilk ( $\mathrm{pH}$ 6.8) was inoculated with $1 \mathrm{~m} l$ of the culture of lactic acid bacteria. For bifidobacteria, the surface of the inoculated soymilk was covered with sterile liquid paraffin to make an anaerobic condition. The inoculated soymilk was incubated at $37^{\circ} \mathrm{C}$ for $24 \mathrm{hrs}$. The titratable acidity and $\mathrm{pH}$ value of the fermented soymilks were measured.

Preparation of extracts from soybean and fermented soymilk

The slurry prepared from the soybeans soaked with water as described above was heated in a boiling water bath for 0 to $60 \mathrm{~min}$ and centrifuged at $18000 \mathrm{rpm}$ for $30 \mathrm{~min}$. The supernatant was filtered through a polysulfone aceptic unit with a $0.45 \mu \mathrm{m}$ membrane (Advantec) and the filtrate was used as the water extract of soybean for assay. One gram of the lyophilized soymilk and fermented milk was added to $10 \mathrm{~m} l$ of water and the mix- 
ture was stirred for $5 \mathrm{~h}$ at room temperature. After $\mathrm{pH}$ adjustment to 4.7 and centrifugation, the water extracts were obtained as described above. The methanol extracts were also prepared from a mixture of $1 \mathrm{~g}$ of the lyophilizates and $15 \mathrm{ml}$ of $80 \%$ methanol.

\section{Results and Discussion}

Antimutagenic activity of aqueous extract from soymilk

The antimutagenic effect of an aqueous extract of the soymilk on the mutagenesis of MNNG toward E. coli B/r WP $2 \operatorname{Trp}^{-}$is shown in Table 1. The numbers of mutant $\left(\operatorname{Trp}^{+}\right)$ colonies decreased by addition of the extract to the plate, and the mutation frequency was also decreased by a dose amount of $60 \mu \mathrm{l}$. However, a dose amount of more than $80 \mu l$ tended to increase the mutation frequency.

Influence of heat treatment of watersoaked soybean on antimutagenic activity

In order to observe the influence of heat treatment of the extract on the antimutagenic effect, aqueous extracts were prepared from soybeans soaked in water and heated in boiling water for different times. The antimutagenic effect of these extracts on the MNNG mutagenesis is shown in Table 2. The number of mutant $\left(\operatorname{Trp}^{+}\right)$colonies did not change in the extracts heated for 0 up to $30 \mathrm{~min}$. However, the extracts heated for 40 and $60 \mathrm{~min}$ lowered the number of mutant $\left(\operatorname{Trp}^{+}\right)$colonies and suppressed the mutagenesis of MNNG toward E. coli by $13-18 \%$. MoriTa et al. ${ }^{1}$ reported that the desmutagenic factor in a water extract prepared from cabbage was sensitive to

Table 1 Antimutagenic effect of the aqueous extract of soymilk on the mutagenesis of MNNG toward Escherichia coli B/r WP 2 Trp $^{-}$

\begin{tabular}{ccccc}
\hline \hline $\begin{array}{l}\text { Aqueous } \\
\text { extract } \\
\text { added } \\
(\mu l)\end{array}$ & $\begin{array}{l}\text { Mean number of } \\
\text { mutant }\left(\operatorname{Trp}^{+}\right) \\
\text {colonies } \\
\text { per plate }\end{array}$ & $\begin{array}{l}\text { Mean number of } \\
\text { survival (Trp }) \\
\text { colonies per } \\
\text { plate }\left(\times 10^{7}\right)\end{array}$ & $\begin{array}{l}\text { Mutation } \\
\text { frequency } \\
\left(\times 10^{8}\right)\end{array}$ & $\begin{array}{c}\text { Percentage } \\
\text { inhibition } \\
(\%)\end{array}$ \\
\hline 0 & 1136 & 102 & 1113 & 0 \\
20 & 934 & 112 & 833 & 25.2 \\
40 & 926 & 112 & 827 & 25.7 \\
60 & 886 & 112 & 791 & 28.9 \\
80 & 873 & 110 & 794 & 28.7 \\
100 & 916 & 104 & 881 & 20.8 \\
\hline
\end{tabular}

Table 2 Changes in the antimutagenicity of the aqueous extracts of soybeans heated at $100^{\circ} \mathrm{C}$ for different times on the mutagenesis of MNNG toward Escherichia coli B/r WP 2 Trp $^{-}$

\begin{tabular}{ccccc}
\hline \hline $\begin{array}{c}\text { Heated } \\
\text { time } \\
(\mathrm{min})\end{array}$ & $\begin{array}{l}\text { Mean number of } \\
\left.\text { mutant (Trp }{ }^{+}\right) \\
\text {colonies } \\
\text { per plate }\end{array}$ & $\begin{array}{l}\text { Mean number of } \\
\text { survival (Trp } \\
\text { colonies per } \\
\text { plate }\left(\times 10^{7}\right)\end{array}$ & $\begin{array}{l}\text { Mutation } \\
\text { frequency } \\
\left(\times 10^{8}\right)\end{array}$ & $\begin{array}{c}\text { Percentage } \\
\text { inhibition } \\
(\%)\end{array}$ \\
\hline Control & 1072 & 94 & 1140 & 0 \\
0 & 1102 & 97 & 1136 & 0.4 \\
10 & 1112 & 98 & 1135 & 0.4 \\
20 & 1128 & 100 & 1128 & 1.1 \\
30 & 1124 & 101 & 1113 & 2.4 \\
40 & 930 & 100 & 930 & 18.4 \\
50 & 978 & 102 & 959 & 15.9 \\
60 & 997 & 101 & 987 & 13.4 \\
\hline
\end{tabular}

Assay was carried out using $100 \mu l$ of water (control) and the extract. 
heating in boiling water. SHINOHARA et al. ${ }^{3)}$ suggested that heat stable antigens exist in the aqueous dialyzates of vegetables. In the aqueous extract of soybeans, the antimutagenic effect was increased by heating them at $100^{\circ} \mathrm{C}$ for more than $40 \mathrm{~min}$. This suggests that the antimutagenic activity in the extract of soybeans could not be lost by the heat treatment for the preparation of soymilk.

Antimutagenic activity of $80 \%$ methanol extract of soymilk

The antimutagenic effect of $80 \%$ methanol extracts on the mutagenesis of MNNG toward E. coli is shown in Table 3. The MNNG mutagenesis was suppressed by $22-24 \%$ by the extract of soymilk at a dose amount of 20-60 $\mu l$. However, there was a tendency for the antimutagenic effect to be reduced at dose amount of more than $80 \mu l$ as observed with the aqueous extract. A marked difference in the animutagenic effect was not observed between the aqueous and $80 \%$ methanol extracts.

Antimutagenic activities of $80 \%$ methanol extracts from fermented soymilks

The $\mathrm{pH}$ values and titratable acidities of soymilks fermented by strains of bifidobacteria and lactic acid bacteria are shown in Table 4. The extent of fermentation in the soymilks was clearly different among the bacterial strains. The strains other than S. thermophilus, L. acidophilus and $L$. bulgaricus lowered the $\mathrm{pH}$ value to less than 5.0. The acidity increased significantly in the soymilk fermented by $B$. breve and $B$. infantis. A bacterial strain having the ability to increase the acidity at more than 0.7 is thought to be suitable for the preparation of fermented soymilk.

The antimutagenic effect of the $80 \%$ methanol extracts from fermented milks is shown in Table 5. The mutation frequencies in the fermented soymilks with bifidobacteria and lactic acid bacteria other than $B$. infantis were lower than that of the control containing only MNNG. The soymilks fermented by $B$. adolescentis, $B$. breve, $B$. longum and $S$. lactis showed higher antimutagenic effect than unfermented soymilk. The extracts of fermented soymilks by $B$. longum and $B$. breve strongly suppressed the mutagenesis of MNNG toward $E$. coli compared with those by other strains.

Table 4 Titratable acidities and $\mathrm{pH}$ values of soymilks fermemted by bifidobacteria and lactic acid bacteria at $37^{\circ} \mathrm{C}$ for $24 \mathrm{~h}$

\begin{tabular}{lcc}
\hline \hline \multicolumn{1}{c}{ Species } & $\mathrm{pH}$ & Acidity(\%) \\
\hline Control & 6.80 & 0.20 \\
B. adolescentis & 4.51 & 0.78 \\
B. bifidum & 4.96 & 0.59 \\
B. breve & 4.55 & 0.87 \\
B. infantis & 4.51 & 0.87 \\
B. longum & 4.91 & 0.66 \\
S. lactis & 4.63 & 0.81 \\
S. thermophilus & 5.44 & 0.30 \\
L. acidophilus & 5.44 & 0.40 \\
L. bulgaricus & 6.09 & 0.21 \\
\hline
\end{tabular}

Table 3 Antimutagenic effect of the $80 \%$ methanol extract of soymilk mutagenesis of MNNG toward Escherichia coli $\mathrm{B} / \mathrm{r}$ WP $2 \mathrm{Trp}^{-}$

\begin{tabular}{ccccc}
\hline \hline $\begin{array}{l}\text { Methanol } \\
\text { extract } \\
\text { added } \\
(\mu l)\end{array}$ & $\begin{array}{l}\text { Mean number of } \\
\text { mutant }\left(\operatorname{Trp}^{+}\right) \\
\text {colonies } \\
\text { per plate }\end{array}$ & $\begin{array}{l}\text { Mean number of } \\
\text { survival (Trp }) \\
\text { colonies per } \\
\text { plate }\left(\times 10^{7}\right)\end{array}$ & $\begin{array}{c}\text { Mutation } \\
\text { frequency } \\
\left(\times 10^{8}\right)\end{array}$ & $\begin{array}{c}\text { Percentage } \\
\text { inhibition } \\
(\%)\end{array}$ \\
\hline 0 & 1168 & 106 & 1102 & 0 \\
20 & 928 & 109 & 851 & 22.8 \\
40 & 856 & 102 & 839 & 23.9 \\
60 & 770 & 106 & 726 & 24.1 \\
80 & 854 & 100 & 854 & 22.5 \\
100 & 916 & 100 & 916 & 16.9 \\
\hline
\end{tabular}


Table 5 Antimutagenic effect of $80 \%$ methanol extract from fermented soymilk by bifidobacteria or lactic acid bacteria on the mutagenesis of MNNG toward Escherichia coli B/r WP 2 $\operatorname{Trp}^{-}$

\begin{tabular}{lcccc}
\hline Species & $\begin{array}{l}\text { Mean number of } \\
\text { mutant (Trp } \\
\text { colonies } \\
\text { per plate }\end{array}$ & $\begin{array}{l}\text { Mean number of } \\
\left.\text { survival (Trp }{ }^{-}\right) \\
\text {colonies per } \\
\text { plate }\left(\times 10^{7}\right)\end{array}$ & $\begin{array}{c}\text { Mutation } \\
\text { frequency } \\
\left(\times 10^{8}\right)\end{array}$ & $\begin{array}{c}\text { Percentage } \\
\text { inhibition } \\
(\%)\end{array}$ \\
\hline Control 1 & 1036 & 99 & 1047 & 0 \\
Control 2 & 939 & 114 & 824 & 21.3 \\
B. adolescentis & 879 & 109 & 806 & 24.0 \\
B. bifidum & 933 & 94 & 993 & 5.2 \\
B. breve & 404 & 72 & 561 & 46.4 \\
B. infantis & 1284 & 110 & 1167 & -11.5 \\
B. longum & 550 & 81 & 679 & 35.1 \\
S. lactis & 1144 & 149 & 768 & 26.6 \\
S. thermophilus & 1234 & 145 & 851 & 18.7 \\
L. acidophilus & 1126 & 119 & 943 & 9.9 \\
L. bulgaricus & 1136 & 139 & 837 & 20.1 \\
\hline
\end{tabular}

Control 1: added $50 \mu l$ of $80 \%$ methanol to the medium.

Control 2 : added the extract of unfermented soymilk.

In the water extracts of soymilk fermented by $B$. longum, $B$. breve and $B$. adolescentis, the antimutagenic effect was also observed at almost the same level as those of the $80 \%$ methanol extracts. The extract of soymilk fermented by $B$. infantis increased the MNNG mutagenesis toward $E$. coli. This bacteria may produce an effector to enhance the MNNG mutagenesis. It is apparent that the antimutagenic activity is not always related to the extent of fermentation indicated by $\mathrm{pH}$ value and titratable acidity of the fermented soymilk.

According to Hosono et ll. $^{8)}$, cow's milks cultured with lactic acid bacteria such as $L$. bulgaricus and $S$. thermophilus have strong antimutagenic activity against AF-2, $4 \mathrm{NQO}$ and MNNG. They also observed that the antimutagenic activities were lost by heating the cultured milk to temperatures higher than $55^{\circ} \mathrm{C}$. In the extracts of fermented soymilks, the antimutagenic activities were not as strong as those of the fermented cow's milks obtained by them. The difference can be ascribed to the preparation of the sample used for the assay and the composition of the cow's milk and soymilk. To compare the antimutagenic act- ivity of fermented soymilk with that of fermented cow's milk, it is further necessary that the antimutagenic activity is assayed for the sample of both milks prepared by the same procedure. Our observations were limited to the use of $80 \%$ methanol extracts from fermented soymilks. However, the antimutagenic activity related to the fermented cow's milk has also been observed in the cell walls of certain lactic acid bacteria ${ }^{16)}$ and acetone or ethyl acetate extracts from the milk ${ }^{9}$.

According to EBATA et al. ${ }^{17)}$ the $\beta$-glucosidase produced by Rhizopus oligosporus could be involved in the formation of antioxidants in the medium containing soybean paste. The increase in the antimutagenic activity of $80 \%$ methanol extract from fermented soymilk is expected to be associated with the action of $\beta$-glycosidase produced by the bacterial strain during the fermentation on the components of soymilk such as isoflavones. Further work is needed to elucidate the antimutagenic factor formed during the fermentation of soymilk.

\section{References}

1) Morita, K., HARA, M. and KadA, T. : Agric. Biol. Chem., 42, 1235 (1978). 
2) Inoue, T., Morita, K. and KadA, T.: Agric. Biol. Chem., 45, 345 (1981).

3) Shinohara, K., Kuroki, S., Miwa, M. Kong, Z.-L. and Hosoda, H. : Agric. Biol. Chem., 52, 1369 (1988).

4) Yoshikawa, K., MuI, K., Ishis, R., Terashita, T., Shishiyama, J. and Kono, M. : Mem. Fac. Agr. Kinki Univ., 23, 55 (1990).

5) Shinohara, K., Fukuda, T., Iino, K. and Kong, Z.-L.: Nippon Shokuhin Kogyo Gakkaishi, 38, 235 (1991).

6) Ueda, S., Kuwahara, Y., Hirai, N., Sasaki, H. and Sugahara, T.: Nippon Shokuhin Kogyo Gakkaishi, 38, 507 (1991).

7) Obata, H., Nakamura, S. and Tanaka, R. : Mutation Research, 175, 47 (1986).

8) Hosono, A., Kashina, T. and KadA, T.: J. Dairy Sci., 69, 2237 (1986).

9) Bodana, A.R. and RAo, D.R. : J. Dairy Sci., 73, 3379 (1990).

10) Shelef, L.A., BAhnmiller, K.R., Zemel, M.B and Monte, L.M. : J. Food Process Preserv., 12, 187 (1988).

11) Buono, M.A. Setser, C., Erickson, L.E. and Fung, D.Y.C.: J. Food Sci., 55, 528 (1990).

12) Angeles, A.G. and Marth, E.H. : J. Milk Food Technol., 34, 124 (1971).

13) Patel, A.A. and GuptA, S.K.: J. Food Protection, 45, 620 (1982).

14) Mital, B.K. and Steinkraus, K.H. : $J$. Milk Food Sci., 40, 114 (1975).

15) Kada, T. and Kanematsu, N.: Proc. Japan Acad., 54, 234 (1978).

16) Hosono, A., Yoshimura, A. and Otani, H. : Milchwissenschaft, 43, 168 (1988).
17) Ebata, J., Fukuda, Y., Hirai, K. and Murata, K. : Nippon Nogeikagaku Kaishi, 46, 323 (1972)

(Received Feb. 13, 1992)

\section{ビフィズス菌および乳酸菌による発酵豆乳の水 およびメタノール抽出物の抗突然変異性}

$$
\begin{aligned}
& \text { 清澤 功* - 松山 惊* - 新井千秋 }{ }^{* *} \\
& \text { *玉川大学農学部農芸化学科 }
\end{aligned}
$$

（テ103 東京都中央区日本橋小伝馬町 20-3）

大豆ならびにビフィズス菌および乳酸菌発酵豆乳の水 および $80 \%$ メノール抽出液の抗突然変異性について 調べた。抽出液の抗突然変異性は，Escherichia coli B/r WP $2 \operatorname{trp}^{-}$の N-methyl-N'-nitroso-N-nitrosoguanidine（MNNG）による誘発突然変異に対する 阻害性によって観察した. 加熱した水浸漬大豆の水抽出 液では， $100^{\circ} \mathrm{C} ， 40$ 分以上加熱すると抗突然変異性が高

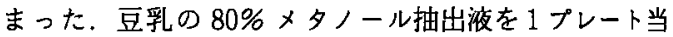
たり 20〜 60 $\mu l$ 添加した場合，22２4\%の抗突然変異 性を示した。発酵豆乳の $80 \%$ メノール抽出液につい て, Bifidobacterium breve およびB. longum では それぞれ 46.4 および $35.1 \%$ となり，末発酵豆乳の $21.3 \%$ よ高い抗突然变異性を示した. B. adolescentis および B. bifidumではそれぞれ24.0および 5. $2 \%$ となった．しかし，B. infantis では突然変異を 高める傾向が認められた，乳酸菌では，Streptococcus lactis が $26.6 \%$ となり，末発酵豆乳より高かった. $S$. thermophilus, Lactobacillus acidophilus おょび L. bulgaricus では, いずれも低くなった. 